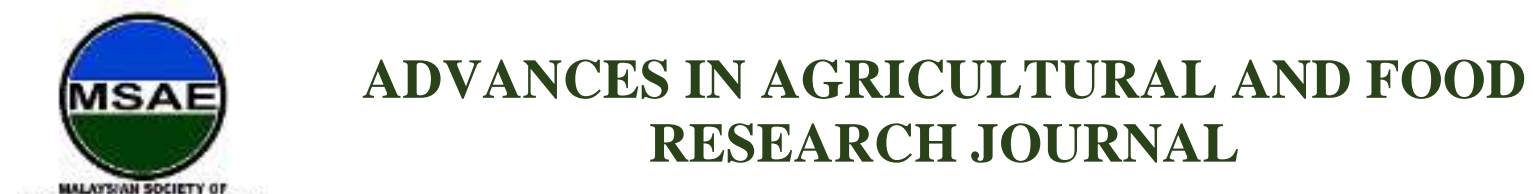

HH PUBLISHER

Original Research Article

\title{
Performance Evaluation and Viability of a Pedestrian- type Low Land Cabbage Transplanter
}

\author{
Mohd Fazly Mail ${ }^{1 *}$, Hafidha Azmon ${ }^{1}$, Mohd Shahmihaizan Mat Jusoh ${ }^{1}$, Mohd Nur Hafiz Mat Azmin², Mohd \\ Nadzim Nordin ${ }^{1}$, Mohd Zubir Md Idris ${ }^{1}$ \\ ${ }^{1}$ Farm Mechanisation Program, Engineering Research Centre, Malaysian Agricultural Research and
Development Institute (MARDI), Serdang, Selangor \\ ${ }^{2}$ Technology Commercialization and Business Centre, Malaysian Agricultural Research and Development \\ Institute (MARDI), Serdang, Selangor. \\ *Corresponding author: Mohd Fazly Mail, Farm Mechanisation Program, Engineering Research Centre, Malaysian \\ Agricultural Research and Development Institute (MARDI), Serdang, Selangor: fazlym@ mardi.gov.my
}

Abstract: This article reports on the performance and costs of owning and operating a pedestrian-type low land cabbage transplanting machine. The tests were carried out on tintailing soil at MARDI Kundang Research Station. They were undertaken in view of the need to mechanize low land cabbage transplanting operation due to shortage of agricultural labours. The machine performed satisfactorily when operated on planting bed with or without the existence of the plastic mulch. Cabbage seedlings required bigger holes on the planting bed which is layered with plastic mulch to avoid mortality of seedlings due to the heat absorbed by the plastic. Based on the performances test, the results showed that the field efficiency were $91.36 \%$ and $92.21 \%$ for with and without plastic mulch respectively on the planting bed. On average, 407s were recorded for the machine to transplant the seedlings along $100 \mathrm{~m}$ planting bed. Compared with the traditional method, the transplanter gives $82-$ $85 \%$ saving in labours that required to plant the seedlings. The calculation of break-even annual use for the implement was $33 \mathrm{ha} /$ year. The implement was projected to be viable to use for $1600 \mathrm{~h} /$ year.

Keywords: low land cabbage; transplanter; machine performance; work rate, viability

Received: $14^{\text {th }}$ September 2020

Accepted: $14^{\text {th }}$ October 2020

Available Online: $26^{\text {th }}$ October 2020

Citation: Mohd Fazly M, Hafidha A, Mohd Shahmihaizan MJ, et al. Performance evaluation and viability of a pedestrian-type low land cabbage transplanter. Adv Agri Food Res J 2020; 1(2): a0000123. https://doi.org/10.36877/aafrj. a0000123

\section{Introduction}

Cabbage or scientifically known as Brassica oleracea var. Capitata belongs to Brassicaceae family which is grown at temperate and subtropical regions (Peter \& Hazra, 2015). The most extensive types of cabbages that cultivated in Malaysia are from variety of round and Chinese cabbages. The total planted area for round cabbage in Malaysia is about 3,677 ha which is equal to $83,600 \mathrm{mt}$ of production while Chinese cabbages covered 552 ha area which can produce $11,912 \mathrm{mt}$ fresh product per year (DOA, 2019). Pahang is the state 
leading producer of round cabbages accounting for 72,104 mt in 2018, followed by Sabah with 7,776 mt and Kelantan in the third place with $528 \mathrm{mt}$ (DOA, 2019). All producers are located at temperate regions and highland which is ideal to cultivate the round cabbages.

Cabbages nowadays can be produced in lowland areas to cater the domestic demand and in consideration of lack of additional spaces to cultivate cabbages at highland areas (Farahzety et al., 2017). Production of low-land cabbages are encouraged by the government as it can be grown in large scale on the flat land with mechanisation. Low productivity of current cabbage cultivation in Malaysia is due to traditional approach in farming activities. Difficulties in operating machineries on hillside enforced to manual operations for cabbage productions. It is different from producing cabbages in low-land, whereby the ground enable mechanization which initiated by engines such as tractors and power tillers. (McNulty \& Grace, 2009). Agricultural mechanizations are the key to improve consistency of plant spacing, ensuring better seedling distribution, optimizing the input usage, reducing labours in field but still able to maintain high productivity (Reid, 2011).

Cabbages can be grown by seeding directly in field or by transplanting seedlings that raised in nurseries (FAO, 2012). In Malaysia, cabbage is commonly grown from transplants and the activity is laborious, back breaking and time consuming when it is implemented manually. The conventional practice requires labours to bend the body and squat in order to punch a hole on the ground and plant seedlings by pressing down the root ball in the soil with hands (Khadatkar et al., 2018). The existence of plastic mulch for weed control has aggravated the difficulties to the labours to prepare a planting hole on a raised bed. Besides, traditional punching holes process on plastic mulching consumes a lot of time to ensure the plastic is fully torn and holes spacing are accurate to allow growth of the plants after seedling planting. The plant spacing is an important factor as it can influence on marketable yield, head diameter and volume of cabbage production (Znidarcic et al., 2007; Rahman et al., 2007).

The labours requirement and consistency in preparing plant spacing are the factors in cabbage productions that show the necessities for mechanizations of transplantations. Transplanters are designed based on seedling type to be used in the field. Cabbage seedlings are categorized as root-ball type, thus the transplanter machine is needed to handle seedlings with extra care to avoid any damage to the root while putting the seedlings into the raised bed. Cabbage transplanter can be found in the market in two forms; automatic and semiautomatic version. The pedestrian-type transplanter is an example of semiautomatic transplanter as it requires a labour to manually transfer the seedlings into the pot supply while automatic tranplanter can eliminate labour as it can self-pick up the seedling from the production tray into the feeder (Khadatkar et al., 2018; Kumar \& Raheman, 2008).

MARDI has owned the $P H 1-A$ pedestrian-type vegetables transplanter to transplant cabbage in the raised bed plantation. This work was undertaken to evaluate the performance 
of the transplanter to increase the production of low land cabbage through appropriate farm mechanization.

\section{Materials and Methods}

\subsection{Machine Description}

The $P H 1-A$ pedestrian-type low land cabbage transplanter (Figure 1) is a lightweight $(155 \mathrm{~kg})$, compact and semi-automated self-propelled transplanter. The machine is suitable for root-ball type seedlings. The transplanter consists of an air-cooled 4-cycle gasoline engine, a power transmission system, hydraulic system, sensor roller, planting shoe, covering wheels, handlebar, handle assembly with several control levers, rotary pot supply system, both sided seedling racks and farm-wheels.

The working principle of the transplanter is based on manual operations that feeding the root ball seedlings from the rack into the rotary pot supply system. There are total of eight pots. One plate is located under the pots with an outlet to allow the seedlings drop into the planting shoe while it is rotating. The planting shoe assists the seedlings transplant on the planting bed in upright orientation. The planting shoe mechanism was designed to open and close the holding part after planting to ensure not to take off the seedlings or pull off the laying plastic mulch while moving forward. The covering wheels are functioning to place soil around the planted seedlings to keep in upright position. There is planting depth control lever that can be switched up to 15 levels which is equal to $5 \mathrm{~mm}$ different for each level. The hydraulic auto-tracking system controls the vehicle body height. Front and rear vehicle body heights are adjusted by the parallel horizontal link mechanism to keep the planting depth and position stable. The system is supported up to 10-degree inclined angle position. The transplanter has a sensor roller to detect the planting bed surface to permit planting on uneven ridges. The suitable ridge height is below $300 \mathrm{~mm}$. The planting ridge width can be adjusted between $500 \mathrm{~mm}$ to $1070 \mathrm{~mm}$. The transplanter has a plant spacing gauge between $200 \mathrm{~mm}$ to $500 \mathrm{~mm}$.

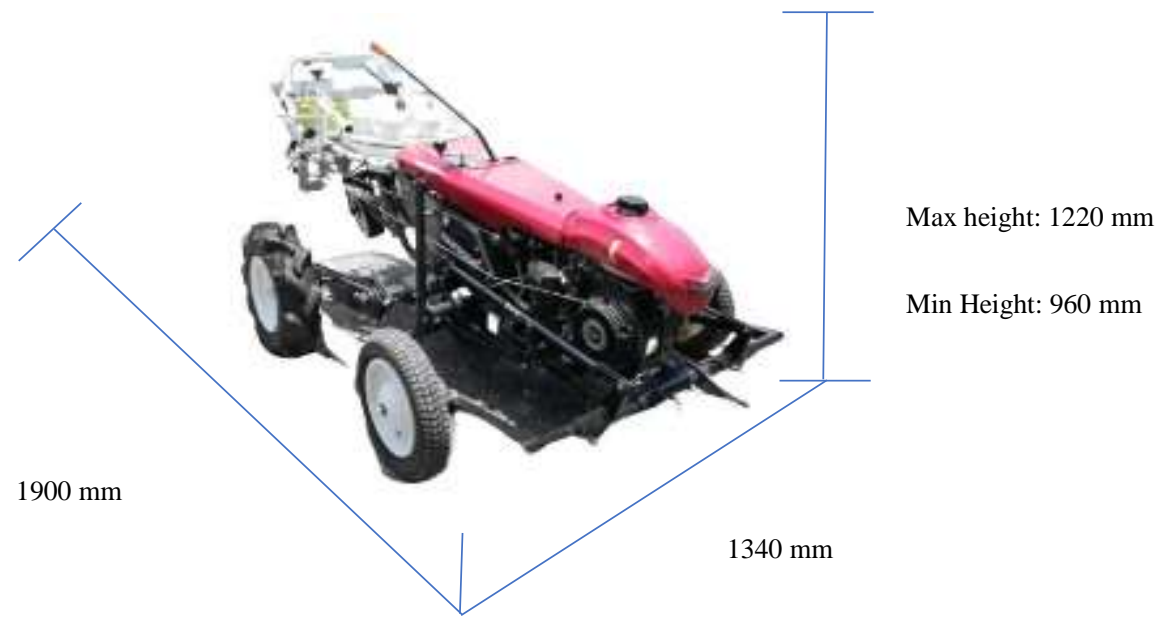

Figure 1. Overall view of the $P H I-A$ pedestrian-type vegetables transplanter. 


\subsection{Functional Performance Test}

The machine mechanical functioning of the transplanter components was observed without taking any work rate data. Observations were made on implement's ease of operation, planting depth control and space lever, gear shift, hydraulic stop lever, sensor roller, covering wheel lever, rotary cup, fuel consumption and working speeds. The observations on operational functional performance were made on the forward speeds suitable for the tin-tailing soil and were repeated several times to get the optimum speed without damaging the seedlings and for the ease of operator in handling the equipment. The completeness of the puncher mechanism that plant the seedlings on the planting bed and suitability of the root ball size to the opening mouth of the planting shoe and the turning circle diameter of the transplanter were also observed.

\subsection{Field Performance Test}

The lowland cabbage transplanter was functionally tested by MARDI Research Station in Kundang. The test plots were of tin-tailing soil with flat to gently rolling topography (0-3 degrees gradient). The test plots were planted with lowland cabbage variety F1 Hybrid 311 at a $0.85 \mathrm{~m}$ between rows and $0.5 \mathrm{~m}$ within rows with $0.05 \mathrm{~m}$ depth. The seedlings were planted in the planting bed without and with plastic mulching. The crop rows in the plot were 97-100 m long. Observations were made and data were collected while the implement was operated in the field doing the various tasks. Total time taken to plant the seedlings on the planting bed for each row over the whole plot, total time taken for stoppages due to implement breakdown or mishandling of the machine and total time taken for turning at the end of the rows were recorded.

\subsection{Performance Analyses and Evaluation}

The machine's theoretical and effective field capacities and field efficiency were analyzed. The test was repeated several times on the tin tailing soil type. The test was compared between the operating on planting bed without and with plastic mulching. At the end of each evaluation the wear occurring on the transplanter was observed. The theoretical field capacity was calculated without considering the time losses during operation (Equation $1)$.

$$
\mathrm{TFC}=\mathrm{W} \times \mathrm{S}
$$

Where,

$T F C=$ theoretical field capacity, $W=$ the width between-row spacing $(\mathrm{m}), S=$ the average forward speed $(\mathrm{m} / \mathrm{s})$.

Time losses during operation such as turning at the end of rows, mishandling and repairing implement breakdown were considered to calculate the effective field capacity (Equation 2). 


$$
\mathrm{EFC}=\mathrm{W} \times \mathrm{S} \times \mathrm{FE}=\mathrm{TFC} \times \mathrm{FE}
$$

Where,

$E F C=$ effective field capacity which is the work rate achieved over the whole plot with considering the total time taken for the work done at the plot,

$F E=$ the field efficiency of the implement under real conditions.

The $F E$ can be calculated by dividing the effective field capacity, $E F C$ and theoretical field capacity, TFC (Equation 3). Field efficiency is normally expressed as percentage.

$$
\mathrm{FE}=\frac{\mathrm{EFC}}{\mathrm{TFC}} \times 100
$$

\subsection{Fuel Consumption}

The fuel consumption was manually estimated to predict the usage of fuel used over time during the machine operation. The tank capacity of the transplanter is two litres. Full tank fuel was filled before starting the operation. After an hour of operation, the tank was refilled to estimate the fuel consumption used.

\subsection{Project Viability and Feasibility}

Project viability and feasibility are the main elements to be of concern before implementing or offering services to the targeted clients. Profit oriented main focus is to ensure all expenses must get return or profit. In other words, it is cost effective and viable. To achieve that purpose, a projected cash flow analysis was developed to get some indicators on its viability and feasibility.

In determining and generating the financial indicators certain assumptions need to forecast based on right study and experiences. Assumptions and data used in estimating the owning and operating cost of PHI-A pedestrian-type transplanter involved are shown in Table 1 below:

Table 1. Assumptions and data used in estimating the owning and operating cost of $P H 1-A$ pedestrian-type transplanter.

\begin{tabular}{cc}
\hline Assumptions & Value \\
\hline Services Covered & 17 ha/month (72ha / year) \\
Working Hours & 8 hours/day
\end{tabular}




\begin{tabular}{cc}
\hline Assumptions & Value \\
\hline Services Price & RM 800/ha \\
Planted Area (Cabbage) in Malaysia & 3,588 ha (DOA, 2018) \\
Potential Market & 68 ha/year (1.9\% from total planted area) \\
Transplanter & RM 40,000 (1 unit) \\
Machine Life Span & 10 years \\
Depreciation \& Amortization & RM 3,600/year \\
Maximum Transplanter Used & 1,600 hours/year \\
Life to Wear Out & 5,000 hours \\
\hline
\end{tabular}

\section{Results}

\subsection{Functional and Field Performance}

The performance of the low land cabbage transplanter under test condition was generally satisfactory. This is especially for the planting function and ease of operation. The transplanter worked easily, quickly and accurately at the test plots. The sensor roller helped the transplanter run efficiently even on uneven soil. The hydraulic auto-tracking system automatically moved up and down based on the unevenness of the soil to keep the transplanter always horizontal position to ensure accurate planting. The seedlings were easily planted on the planting beds on tin-tailing soil conditions with the planting shoe mechanism. The planting shoe mechanism succeeded in opening and closing the holding part efficiently without taking off the seedlings and pulling off the laid plastic mulch. The soils were dragged by the covering wheels to cover the seedlings for stable planting after being planted. The planting depth control lever was easily used to switch up for the different of depth level. The planting depth was set at $50 \mathrm{~mm}$ depth as required by the agronomist. In the test, the proportion of seedlings not being in upright orientation after planting was very low, at $5 \%$ of the whole plot.

The theoretical field capacity of the transplanter was obtained by its forward travel speed was measured while transplanting a sample distance with a mean of $98.85 \mathrm{~m}$ in a row for both planting bed without and with plastic mulching (Figure 2), and the planted seedlings on the planting bed were counted. All unproductive tasks were not taken into considerations. Several sample readings were taken to get a representative average reading. The forward speed of the operating transplanter ranged from $0.279 \mathrm{~m} / \mathrm{s}$ to $0.285 \mathrm{~m} / \mathrm{s}$ for ridges without plastic mulching and $0.242 \mathrm{~m} / \mathrm{s}$ to $0.260 \mathrm{~m} / \mathrm{s}$ for ridges with mulch. From the data, the corresponding mean spot work rate was estimated at $0.0853 \mathrm{ha} / \mathrm{h}$ and 0.0752 for planting bed without and with plastic mulching respectively. 
The effective field capacity was obtained after considering the time losses for unproductive tasks such as turning at headland, travelling from one planting row to another, unloading empty trays and taking new seedling trays. The time taken to transplant the whole plot and that for the unproductive tasks were recorded. In the test, the trial plot was 0.221 ha in size. The results obtained for theoretical field capacities and effective field capacity of the low land cabbage planting on tin-tailing soil is summarized in Table 2. The time spent on various field tasks is given in Table 3. Field efficiency level of $91.36-92.21 \%$ obtained in the current field test was very good. The transplanter consumed 1.51 of gasoline fuel hourly.

Table 2. Theoretical field capacities and effective field capacity of the low land cabbage planting on tintailing soil at MARDI Kundang Research Station (based on 0.221 ha plot).

\begin{tabular}{ccccc}
\hline $\begin{array}{c}\text { Planting bed } \\
\text { condition }\end{array}$ & $\begin{array}{c}\text { Forward } \\
\text { speed }(\mathbf{m} / \mathbf{s})\end{array}$ & $\begin{array}{c}\text { Theoretical field } \\
\text { capacity (ha/h) }\end{array}$ & $\begin{array}{c}\text { Effective field } \\
\text { capacity (ha/h) }\end{array}$ & $\begin{array}{c}\text { Seedling planting } \\
\text { rate (seedling/hr) }\end{array}$ \\
\hline $\begin{array}{c}\text { Without plastic } \\
\text { mulching }\end{array}$ & 0.279 & 0.0853 & 0.0786 & 2006 \\
$\begin{array}{c}\text { With plastic } \\
\text { mulching }\end{array}$ & 0.246 & 0.0752 & 0.0687 & 1770 \\
\hline
\end{tabular}

Table 3. Proportion of time spent on various tasks involved in low land cabbage planting.

\begin{tabular}{ccc}
\hline Task & \multicolumn{2}{c}{ Proportion of time spent (\%) } \\
\cline { 2 - 3 } & Without plastic mulching & With plastic mulching \\
\hline $\begin{array}{c}\text { Planting seedlings } \\
\text { Turning and travelling at the } \\
\text { headland }\end{array}$ & 92.21 & 91.36 \\
$\begin{array}{c}\text { Unloading empty tray and } \\
\text { taking new seedlings tray }\end{array}$ & 4.58 & 3.11 \\
\hline
\end{tabular}

Using the pedestrian-type vegetables transplanter, the amount of labour required for transplanting the cabbage seedlings is low. Based on the overall work rate from Table 2, only 12.72-14.56 man-h are required by the transplanter to transplant a hectare of seedlings compared with 85 man-h required by the manual method. This would represent a saving of about $82-85 \%$. The large saving in labour should be attractive to the potential users. 


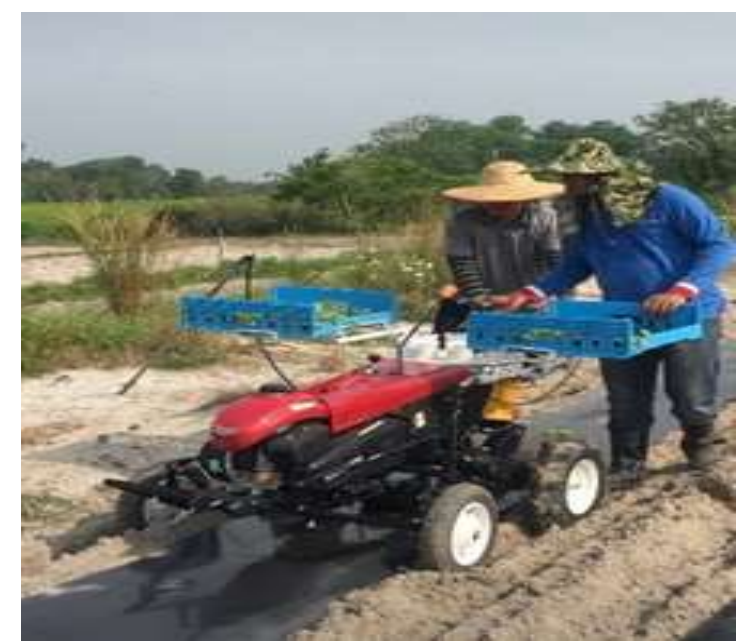

(a)

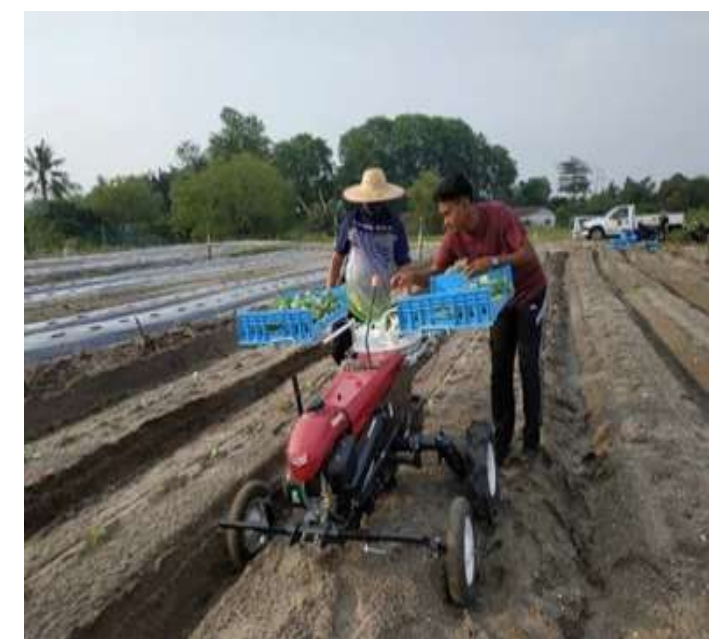

(b)

Figure 2. Transplanter operated on planting bed a) with and b) without plastic mulching.

\subsection{Viability of Owning and Operating}

Five years projected cash flow has been developed by using related assumptions. Generally, the project is viable by referring to the indicators in Table 4:

Table 4. Financial Indicators of the $P H I-A$ transplanter.

\begin{tabular}{ccc}
\hline Indicators & Value & Benchmarking / Guide \\
\hline Net Present Value (NPV) & RM 10,998 & Positive Value (bigger is better) \\
Internal Rate Return (IRR) & $24 \%$ & $>15 \%$ (short cycle crops) \\
Return on Investment (ROI) & $69 \%$ & $>50 \%$ very good \\
Pay Back Period (PBP) & 1.99 years & $>$ Shorter time is better \\
Benefit Cost Ratio (BCR) & 1.62 & $>1(\$ 1.00:$ \$ 1.62$)$ \\
Discount Rate Used / Interest & $10 \%$ & Only 5-8\% /year \\
\hline
\end{tabular}

The cost of production per hectare is RM 615 while recommended production charge is RM 800/ha with 30\% profit margin gain from the services charges. Current charge on planting with conventional way is around RM 1200-1400/ha (price in 2018) which is cheaper around RM 400-600/ha and we gain more profit by using transplanter services.

The viability of owning and operating the transplanter was assessed for the case when it is used for 1,600 hour operating/year. This is equivalent to using it for about 133 hour operating/month. On the other hand, for all machineries they have their own period of life to wear out which is the maintenance needs to be implemented to make sure optimum performance of the machineries. For this transplanter, period life to wear out estimated up to 5,000 hours operation or about three years operation due to rugged design with easily 
replaceable parts. While the transplanter life span estimated until 10 years before not relevant to operate more according this projected cash flow. This project only needs 1.99 years payback period which is sufficient to gain profit from this service.

\section{Discussion}

The performance of the PHI-A pedestrian-type vegetables transplanter on tin-tailing soil was generally satisfactory. The transplanter reduced labour costs as compared with the manual method of transplanting the cabbage seedlings. As conclusion, this project is viable and feasible to be implemented supported by related indicators from projected cash flow analysis based on relevant and reliable assumptions. Furthermore, in new era of agriculture, adaptation of machineries in production become priority to ensure the consistency, quality, accuracy and productivity efficiency are controlled. Without considering the usefulness of machineries, farmers or our agriculture sector will be left behind and hard to compete with advanced agriculture related countries like Thailand, Vietnam and others. Further research needs to be conducted for evaluating the optimum usage of the transplanter with various plant spacings as this paper only report on performance of machine on single plant spacing.

Funding: This research was supported and funded by Mechanization and Automation Fund under the Ministry of Agriculture and Agro Food, Malaysia.

Acknowledgments: The authors thank MARDI Kundang Research Station and their staffs for providing the low land cabbage plots for the tests and their assistance during the field tests. We wished to specially thank our team members Mr. Noraznal Mohd Zainal, Miss Norahshekin Abdul Rahman, Mr. Zawayi Mat, Miss Siti Ashah Abdul Rahim, Zul Fadzli Marzuki, Mohd Khairil Izani Ishak, Ahmad Kamil Zolkafli, Mustafar Yaakob, Muhammad Akmal Mohd Salleh, Zulhazmi Abu Bakar, Joehari Abdul Rani, Mohammad Shamsul Idris, Mohd Rosli Pairan, Zainal Abidin Abu Bakar for their dedication and valuable contributions rendered during the tests conducted on the transplanter.

Conflicts of Interest: The authors declare no conflict of interest, and also the funders had no role in the design of the study; in the collection, analyses, or interpretation of data; in the writing of the manuscript, or in the decision to publish the results.

\section{References}

Agricultural Machinery Management (2000). ASAE Standards, 344-349.

DOA. (2019). Booklet Statistik Tanaman 2019 (Sub-Sektor Tanaman Makanan), Jabatan Pertanian Malaysia. Retrived on $15 \quad$ December 2019 from http://www.doa.gov.my/index/resources/aktiviti_sumber/sumber_awam/maklumat_pertanian/perangkaan_tanam an/booklet_statistik_tanaman_2019.pdf

FAO (2012). Crop water information: Cabbage. Retrieved on 3 March 2020, from http:// www.fao.org/nr/water/cropinfo_cabbage.html.

Farahzety, A. M., Illias, M. K., Rozlaily, Z., et al. (2017). Teknologi pengeluaran kubis bulat tanah rendah secara penanaman terbuka. Prosiding Persidangan Kebangsaan Pemindahan Teknologi (CONFERTECH), 136-143.

Kumar, G. V. P., \& H. Raheman, H. (2008). Vegetable transplanters for use in developing countries-A review. International Journal of Vegetable Science, 14(3), 232-255

Khadatkar, A., Mathur, S. M., \& Gaikwad, B. B. (2018). Automation in transplanting: A smart way of vegetable cultivation. Current Science, 115(10), 1884-1892 
McNulty, P. B., \& Grace, P. M. (2009). Agricultural Mechanization and Automation. Encyclopedia of Life Support Systems, 1, 1-46

Peter, K. V., \& Hazra, P. (2015). Handbook of vegetables, Studium Press LLC.

Reid, J. F. (2011). The impact of mechanization on agriculture. The Bridge, 41(3), 22-29.

Rahman, M., Iqbal, M., Jilani, M. S., et al., (2007). Effect of different plant spacing on the production of cauliflower (Brassica oleraceae var. Botrytis) under the agro-climatic conditions of D.I. Khan. Pakistan Journal of Biological Sciences. 10(24), 4531-4534.

Znidarcic, D., Kacjan-Marsic, N., Osvald, J., et al., (2007). Yield and quality of early cabbage (Brassica oleracea L. var. capitata) in response to within-row plant spacing. Acta agriculturae Slovenica, 89(1), 15-23.

Copyright () 2020 by Mail MF et al. and HH Publisher. This work is licensed under the Creative Commons Attribution-NonCommercial 4.0 International Lisence (CC-BY-NC4.0) 